\title{
Seasonal variation in viral-induced mortality of bacterioplankton in the water column of a large mesotrophic lake (Lake Biwa, Japan)
}

\author{
A. S. Pradeep Ram ${ }^{1,4}$, Y. Nishimura ${ }^{1,5}$, Y. Tomaru ${ }^{2}$, K. Nagasaki ${ }^{2}$, T. Nagata ${ }^{1,3, *}$ \\ ${ }^{1}$ Centre for Ecological Research, Kyoto University, 2-509-3 Hirano, Otsu, Shiga 520-113, Japan \\ ${ }^{2}$ Harmful Algal Bloom Division, National Research Institute of Fisheries and Environment of Inland Sea, \\ Fisheries Research Agency, 2-17-5 Maruishi, Hatsukaichi, Hiroshima 739-0452, Japan \\ ${ }^{3}$ Ocean Research Institute, The University of Tokyo, 1-15-1 Minamidai, Nakano-ku, Tokyo 164-8639, Japan \\ ${ }^{4}$ Present address: Laboratoire ‘Microorganismes: Génome et Environnement', Université Blaise Pascal, Clermont-Ferrand II, \\ UMR CNRS 6023, 63177 Aubiére Cedex, France \\ ${ }^{5}$ Present address: Port and Airport Research Institute, 3-1-1 Nagase, Yokosuka, Kanagawa, 239-0826, Japan
}

\begin{abstract}
Viruses are ubiquitous and abundant in aquatic systems, yet knowledge of virusbacteria interactions in thermally stratified water columns of large lakes is limited. We explored the possible factors that affect viral abundance, infection rate, and the relative importance of viral lysis to heterotrophic nanoflagellate (HNF) grazing as a mortality factor of bacterioplankton in the upper (euphotic zone, $5 \mathrm{~m}$ ) and deeper (aphotic zone, $50 \mathrm{~m}$ ) layers of the large mesotrophic Lake Biwa, Japan. Data obtained for a full seasonal cycle indicated that bacterial abundance was the best predictor $\left(\mathrm{r}^{2}=0.85\right)$ of viral abundance (range $1.0 \times 10^{10}$ to $4.1 \times 10^{10}$ viruses $\mathrm{l}^{-1}$ ), yielding an average virus:bacteria ratio of $8.2 \pm 1.3(\mathrm{SD})$. Variation in the frequency of visibly infected cells (range 1.8 to $4.1 \%$ ) was largely accounted for by the linear combination of bacterial production and HNF abundance $\left(\mathrm{r}^{2}=0.81, \mathrm{p}<0.001, \mathrm{n}=24\right)$. The percentage of daily bacterial production destroyed by viruses was estimated to be high $(52.7 \pm 16.2 \%)$ in the upper layer during the stratification period, which was on average 3.0-fold greater than the percentage of bacterial production consumed by HNF in that layer. In contrast, the corresponding value in the deeper layer was moderate $(13.6 \pm 5.2 \%)$, being 0.6 fold lower than the percentage of bacterial production consumed by HNF. Our data suggest that carbon and nutrient flux patterns controlled by viruses and HNF vary with depth in thermally stratified water columns of Lake Biwa.
\end{abstract}

KEY WORDS: Viruses - Bacteria - Frequency of infected cells $\cdot$ Burst size - Seasonal dynamics · Stratified large lake

Resale or republication not permitted without written consent of the publisher

\section{INTRODUCTION}

Viruses, the most abundant biological entities in aquatic environments (Breitbart \& Rohwer 2005, Suttle 2007), play important roles in ecosystems by regulating carbon and nutrient fluxes, food web dynamics, and bacterial diversity (Fuhrman 1999, Weinbauer 2004). Viral-induced mortality accounts for a significant, albeit highly variable (5 to $80 \%$ ), fraction of bacterial production in aquatic systems (Weinbauer 2004, SimeNgando \& Colombet 2009), which can exceed the mor- tality caused by protist bacterivory depending on the environment (Fuhrman \& Noble 1995, Pradeep Ram et al. 2005). The relative contribution of viral lysis and protist grazing to total bacterial mortality can affect patterns in carbon and nutrient cycling. Theories have predicted that trophic transfer of carbon and nutrient elements residing in bacterial biomass to higher trophic levels (e.g. mesozooplankton) is substantially reduced with increasing viral lytic pressure relative to protist grazing (Fuhrman 1999, Miki et al. 2008, Motegi et al. 2009). Some studies have provided evi- 
dence in support of this prediction (Middelboe et al. 1996, Motegi et al. 2009); however, variations in time and space and viral lytic pressure controls relative to protist grazing and bacterial growth remain unclear, hampering the improvement of ecosystem and biogeochemical models by incorporating viral-mediated processes.

In the present study, we examined variation in viral abundance, viral-induced bacterial mortality, heterotrophic nanoflagellate (HNF) abundance, and related metabolic variables of bacteria in a large mesotrophic freshwater lake (Lake Biwa, Japan). Knowledge of virus-bacteria interactions in large lakes is limited, with few data available on seasonal trends and vertical variation in viral abundance and infectivity (Brum et al. 2005, Pradeep Ram et al. 2009). Stratified water bodies of large lakes are characterized by steep gradients in environmental and bacterial variables with depth (Nishimura et al. 2005), providing a useful test for examining factors controlling virus-HNF-bacteria systems in limnetic environments. In the present study, we collected a full seasonal cycle of samples at 2 depth horizons ( 5 and $50 \mathrm{~m}$ ) in the north basin of Lake Biwa. We explored (1) possible factors that affect viral abundance and infection rate and (2) the relative importance of viral lysis and HNF grazing as mortality factors for bacteria.

\section{MATERIALS AND METHODS}

Study site. Lake Biwa is a large (surface area, $674 \mathrm{~km}^{2}$ ), deep (maximum depth, $104 \mathrm{~m}$ ), tectonic lake located in the central part of Honshu Island, Japan. The present study was conducted in the monomictic, mesotrophic north basin, which has a water residence time of $5.5 \mathrm{yr}$ (Kim et al. 2006).

Sampling. Water samples were collected every month at a pelagic station $\left(35^{\circ} 212.932^{\prime} \mathrm{N}, 135^{\circ} 59.897^{\prime} \mathrm{E}\right.$; maximum depth, ca. $70 \mathrm{~m}$ ) from April 2005 through April 2006. Sample waters were collected at depths of 5 and $50 \mathrm{~m}$ with a clean 51 Niskin X bottle (General Oceanics). Water temperature depth profiles were obtained using a CTD probe (SBE 911 plus; Sea Bird Electronics).

Viral and bacterial abundance. For enumeration of viruses and bacteria, water samples $(50 \mathrm{ml})$ were fixed immediately with $0.02 \mu \mathrm{m}$ filtered, buffered formalin (final concentration, $2 \% \mathrm{v} / \mathrm{v}$ from a $37 \% \mathrm{w} / \mathrm{v}$ solution of commercial formaldehyde). Within $2 \mathrm{~h}$ of fixation, the subsamples (1 to $2 \mathrm{ml}$ ) were filtered $(<15 \mathrm{kPa}$ vacuum) through Anodisc filters $(0.02 \mu \mathrm{m}$ pore size; Whatman), using cellulose acetate backing filters $(1.2 \mu \mathrm{m}$ pore size). Following SYBR Green I staining (Molecular Probes; final dilution, $2.5 \times 10^{-3}$ fold) as described by Noble \& Fuhrman (1998), the filters were air-dried on absorbent paper and mounted between a slide and glass cover slip with an antifading mountant (Citifluor) amended with approximately $20 \%$ (v/v) Vecta Shield (Vector Laboratories). If not immediately analyzed, the slides were stored at $-20^{\circ} \mathrm{C}$ until counting under an epifluorescent microscope (Olympus BX 50). A blank was routinely examined to control for contamination of the equipment and reagents.

Bacterial production (BP), respiration (BR), and growth efficiency (BGE). BP was measured by the leucine (Leu) method (Kirchman et al. 1985). For each sample, triplicate aliquots $(5 \mathrm{ml})$ and a trichloroacetic acid (TCA)-killed control were incubated with $20 \mathrm{nM}$ $\left[{ }^{3} \mathrm{H}\right]$ Leu (final concentration; Amersham) for 1 to $1.5 \mathrm{~h}$ at in situ temperature in the dark (the incubation period was chosen on the basis of previous results indicating the linearity over 1 to $2 \mathrm{~h}$ of the bacterial incorporation of ${ }^{3} \mathrm{H}$-thymidine in Lake Biwa; Nagata 1987b). Samples were filtered through $0.22 \mu \mathrm{m}$ pore-size membrane filters (25 mm diameter; Millipore GS) and rinsed twice with $3 \mathrm{ml}$ cold TCA and $3 \mathrm{ml}$ ice-cold $80 \%$ ethanol. BP in the size-fractionated samples was also determined to derive $\mathrm{BGE}(\mathrm{BGE}=\mathrm{BP} /(\mathrm{BP}+\mathrm{BR})$; note that $\mathrm{BR}$ was determined for size-fractionated samples in order to minimize the inclusion of respiration by phytoplankton and protists (see next paragraph). After incubation with ${ }^{3} \mathrm{H}-\mathrm{Leu}$, samples were filtered through $0.8 \mu \mathrm{m}$ pore-size Nucleopore filters (Whatman). The filtrates were filtered through $0.22 \mu \mathrm{m}$ pore-size membrane filters (25 $\mathrm{mm}$ diameter; Millipore GS) and rinsed twice with $3 \mathrm{ml}$ cold TCA and $3 \mathrm{ml}$ ice-cold $80 \%$ ethanol. BP determined for the total and $<0.8 \mu \mathrm{m}$ fraction was denoted as $\mathrm{BP}_{\text {total }}$ and $\mathrm{BP}_{<0.8}$, respectively. The filters were dried and solubilized with $1 \mathrm{ml}$ ethyl acetate. Scintillation cocktail (Ultima-Gold, Packard Instruments) was added to each vial, and radioactivity was determined using an LKB Wallac 1000 liquid scintillation counter. Leu incorporation rate was converted to bacterial carbon production and bacterial cell production using a conversion factor of $1.5 \mathrm{~kg} \mathrm{C} \mathrm{mol} \mathrm{Leu}{ }^{-1}$ and $1.2 \times 10^{17}$ cells mol Leu ${ }^{-1}$, respectively (Kirchman et al. 1995). We assumed that the incorporation of ${ }^{3} \mathrm{H}$ Leu was maximized at the added concentration of $20 \mathrm{nM}$. It could be under the level of saturation at certain periods of the year especially in the upper layer, which may result in changes in isotope dilution (Jørgensen 1992). However, Pace \& Cole (1996) reported that the addition of $17 \mathrm{nM}$ of Leu was sufficient to maximize the incorporation rate in lakes. We note that the conversion factors that we used in the present study are those obtained in marine waters (Kirchman et al. 1995), which are consistent with 'theoretical' conversion factors with an assumption of minimal isotope dilution (Simon \& Azam 1989). Although similar conversion factors have been reported in freshwater sys- 
tems (Jørgensen 1992), conversion factors may be affected by multiple factors including isotope dilution, protein turnover, and the carbon content per cell (Kirchman 2001). Thus, our estimates of BP derived by using a fixed conversion factor could have errors due to variations in physiological states of bacterial communities in our samples.

BR was measured using sample waters prefiltered through GF/F (Whatman, $142 \mathrm{~mm}$ in diameter) by gravity using an inline filtration manifold (ADVANTEC KS-142), except that $0.8 \mu \mathrm{m}$ polycarbonate filters (Whatman) were used in April 2005. The filtrate was carefully transferred to calibrated borosilicate glass BOD bottles (300 ml capacity) to avoid air-bubble formation. Time-zero control samples were immediately fixed with Winkler's reagents. Samples were incubated in a water bath at in situ temperature $\left( \pm 1^{\circ} \mathrm{C}\right)$ in the dark for 12 to $24 \mathrm{~h}$. Triplicate bottles were used to determine the initial and final oxygen concentrations. Concentrations of dissolved oxygen were determined by the Winkler method (azide modification) using a high precision $( \pm 2.0 \mu \mathrm{l})$ Metrohm 716 DMS titrator (Carignan et al. 1998). We used a factor of 0.375 to

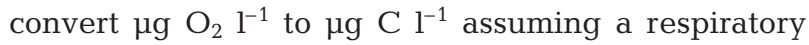
quotient of 1.

BGE was calculated according to the following equation: $\mathrm{BGE}=\mathrm{BP}_{<0.8} /\left(\mathrm{BP}_{<0.8}+\mathrm{BR}\right)$. Because we used GF/F (except for April 2005) and $0.8 \mu \mathrm{m}$ polycarbonate filters for determining $\mathrm{BR}$ and $\mathrm{BP}_{<0.8}$, respectively, the BGE estimates could have errors due to differences in bacterial retention efficiency between the 2 types of filters. The use of GF/F facilitated the preparation of the volume of water required for determination of respiration, although GF/F filtration may cause the release of dissolved organic matter (DOM) due to the rupture of cells especially when the filter surface is exposed to air after the filtration (Nagata \& Kirchman 1990). In the present study, we minimized the exposure of the filter surface to air by using an inline filtration manifold. However, we cannot exclude the possibility that our respiration data might have errors due to an artificial increase in labile DOM. Keeping these limitations in mind, we used the respiration and BGE data only for correlation analyses with an assumption that the errors associated with these variables were not systematic over seasons and across different layers.

Transmission electron microscope (TEM) analysis of the frequency of visibly infected cells (FVIC). Bacterial cells were collected on triplicate electron microscope grids (400-mesh, carbon-coated Formvar film) by ultracentrifugation (Himac CP 75, Hitachi; P40ST Swing-Out-Rotor at $70000 \times g$ for $20 \mathrm{~min}$ at $4^{\circ} \mathrm{C}$ ) according to Sime-Ngando et al. (1996). Each grid was stained at room temperature (ca. $20^{\circ} \mathrm{C}$ ) for $30 \mathrm{~s}$ with uranyl acetate $(2 \%, \mathrm{pH}=4$; Sime-Ngando \& Pradeep
Ram 2005), rinsed twice with $0.02 \mu \mathrm{m}$ filtered distilled water to remove excess stain, and then dried on filter paper. The samples were examined using a JEOL-JEM 1010 TEM operated at $80 \mathrm{kV}$ and a magnification of 20000 to $60000 \times$ to distinguish between bacterial cells with and without intracellular viruses. A bacterium was considered infected when at least 5 viruses, identified by shape and size, were clearly visible inside the host cell. At least 500 bacterial cells were inspected per grid to determine FVIC. Because mature phages are visible only late in the infection cycle, FVIC counts were converted to frequency of infected cells (FIC) using the equation FIC = 9.524 FVIC - 3.256 (Weinbauer et al. 2002). Assuming that the system is in a steady state, that grazers do not discriminate between infected and uninfected cells, and that the latent period equals the bacterial generation time, then FIC was converted to frequency of bacterial mortality due to viral lysis (FMVL) using the following equation: FMVL $=\left(\right.$ FIC +0.6 FIC $\left.^{2}\right) /(1-1.2 F I C)$ (Binder 1999) Burst size was estimated by enumerating viral particles in infected cells (number of infected cells examined was on average 20 cells sample ${ }^{-1}$; range 15 to 25 ).

HNF abundance and grazing potential. For determining HNF abundance, water samples were fixed with glutaraldehyde (final concentration $2 \% \mathrm{v} / \mathrm{v}$ ). The water samples (20 to $50 \mathrm{ml}$ ) were double-stained with fluorescein isothiocyanate $(0.004 \%$, dissolved in borate buffer of $\mathrm{pH} 9.4)$ and DAPI ( $\left.1 \mu \mathrm{g} \mathrm{ml}^{-1}\right)$ and incubated in the dark for 15 min to enumerate HNF abundance. The samples were then filtered $(<15 \mathrm{kPa}$ vacuum) onto $0.8 \mu \mathrm{m}$ pore-size black polycarbonate filters (25 mm diameter; Whatman) and counted under an epifluorescent microscope (Olympus BX 50 model). At least 20 microscopic fields or $200 \mathrm{HNF}$ cells were counted per slide. To estimate the rate of bacterivory by HNF (cells ml $\mathrm{l}^{-1} \mathrm{~h}^{-1}$ ), we assumed that in $1 \mathrm{~h} \mathrm{HNF}$ clear bacteria from a water volume $10^{5}$ times their own cell volume at $20^{\circ} \mathrm{C}$ (Fenchel 1982) and that the $Q_{10}$ is 2 (Nagata 1988). Total HNF cell volume was estimated by multiplying the HNF cell abundance and the literature value of the average HNF cell volume in Lake Biwa $\left(39.6 \mathrm{~m}^{3} \mathrm{cell}^{-1}\right.$ [at $5 \mathrm{~m}$ ] or $50.9 \mu^{3}$ cell $^{-1}$ [at $50 \mathrm{~m}$ ]; Nagata 1987a) after correcting for cell shrinkage due to fixation (Choi \& Stoecker 1989).

Statistical analyses. Statistical analyses were conducted using SigmaStat (SPSS). Comparisons of multiple mean values were conducted using ANOVA. Relationships among variables were tested by the Pearson correlation analysis and stepwise multiple regression. Values were log-transformed if necessary to meet normality and equal variance assumptions. If these requirements were not met, a non-parametric method (Kruskal-Wallis 1-way ANOVA on ranks with Dunn's test) was used. 


\section{RESULTS}

\section{Temperature and dissolved oxygen}

Water temperature at depth $5 \mathrm{~m}$ increased from $13^{\circ} \mathrm{C}$ in April 2005 to $27^{\circ} \mathrm{C}$ in August and then decreased to $12^{\circ} \mathrm{C}$ in December. Water temperature at depth $50 \mathrm{~m}$ was lower and less variable throughout the investigation period $\left(8.1\right.$ to $\left.8.5^{\circ} \mathrm{C}\right)$. Winter cooling resulted in vertical mixing of the water column and diminished the difference in water temperature between the 5 and $50 \mathrm{~m}$ depths $(\Delta T)$. In the present study, mixing period refers to the months between January and April 2006, when $\Delta T$ was $<0.5^{\circ} \mathrm{C}$. Other months (with $\Delta T>0.5^{\circ} \mathrm{C}$ ) are referred to as the stratification period (between April and December 2005). Oxygen concentrations ranged from 6.8 to $11.4 \mathrm{mg} \mathrm{l}^{-1}$ and 6.5 to $11.3 \mathrm{mg} \mathrm{l}^{-1}$ at depths of 5 and $50 \mathrm{~m}$, respectively.
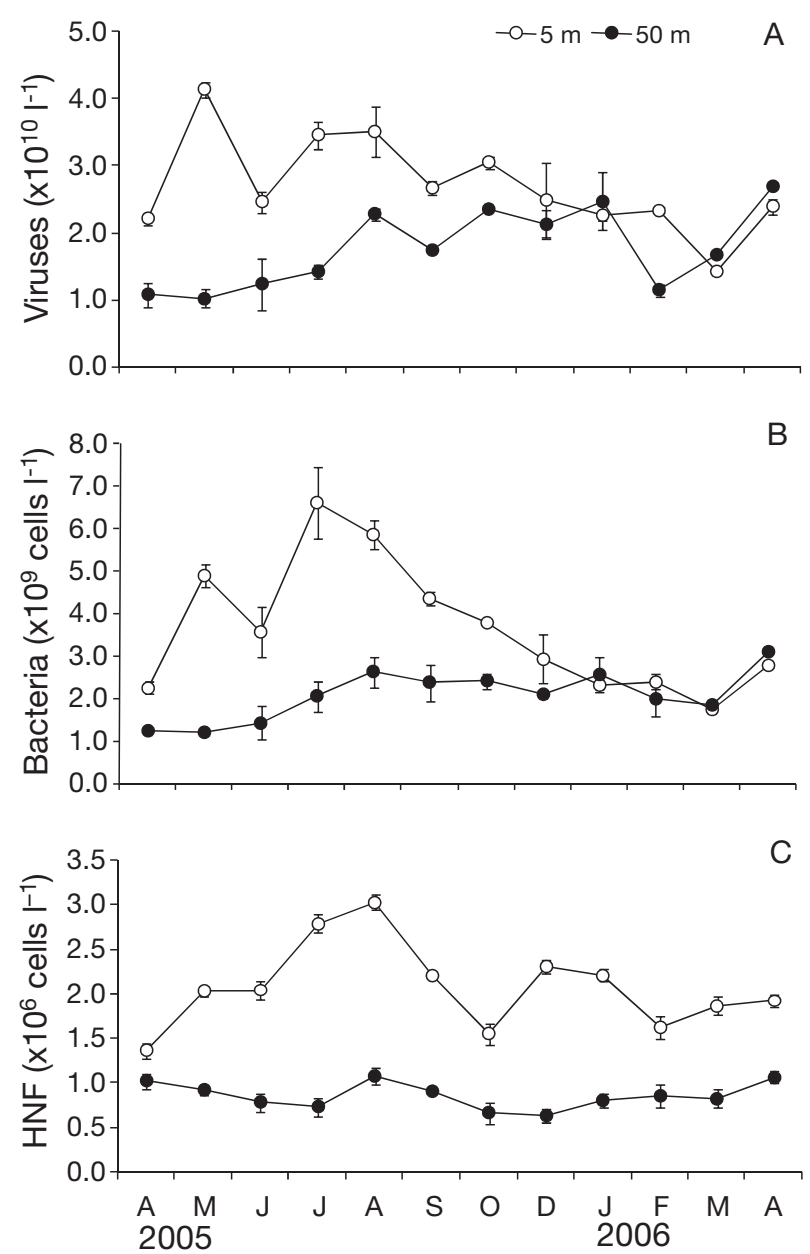

Fig. 1. Seasonal variations in the abundances of (A) viruses, (B) bacteria, and (C) heterotrophic nanoflagellates (HNF) at depths of 5 and $50 \mathrm{~m}$ at a pelagic site of Lake Biwa. Error bars indicate SEM $(\mathrm{n}=3)$

\section{Abundance of viruses, bacteria, and nanoflagellates}

Viral and bacterial abundances were higher and more variable in the upper than the lower layer during the stratification period (May to December; Fig. 1A,B). Mean $( \pm \mathrm{SD}$, here and elsewhere) viral $(3.0 \pm 0.7 \times$ $\left.10^{10} \mathrm{l}^{-1}\right)$ and bacterial $\left(4.3 \pm 1.5 \times 10^{9}\right.$ cells $\left.\mathrm{l}^{-1}\right)$ abundance in the upper layer was significantly $(\mathrm{p}<0.05)$ greater than the corresponding values in the deeper layer (viral abundance $1.7 \pm 0.5 \times 10^{10} \mathrm{l}^{-1}$; bacterial abundance $1.9 \pm 0.6 \times 10^{9}$ cells $^{-1}$; Table 1$)$. During the mixing period (January to April), viral and bacterial abundance was low and differed little between the 2 layers (Fig. 1, Table 1). Despite the large variability in viral and bacterial abundance with depth, the viral abundance to bacterial abundance ratio did not differ significantly $(p>0.05)$ between the upper and lower layers during the stratification period; the average
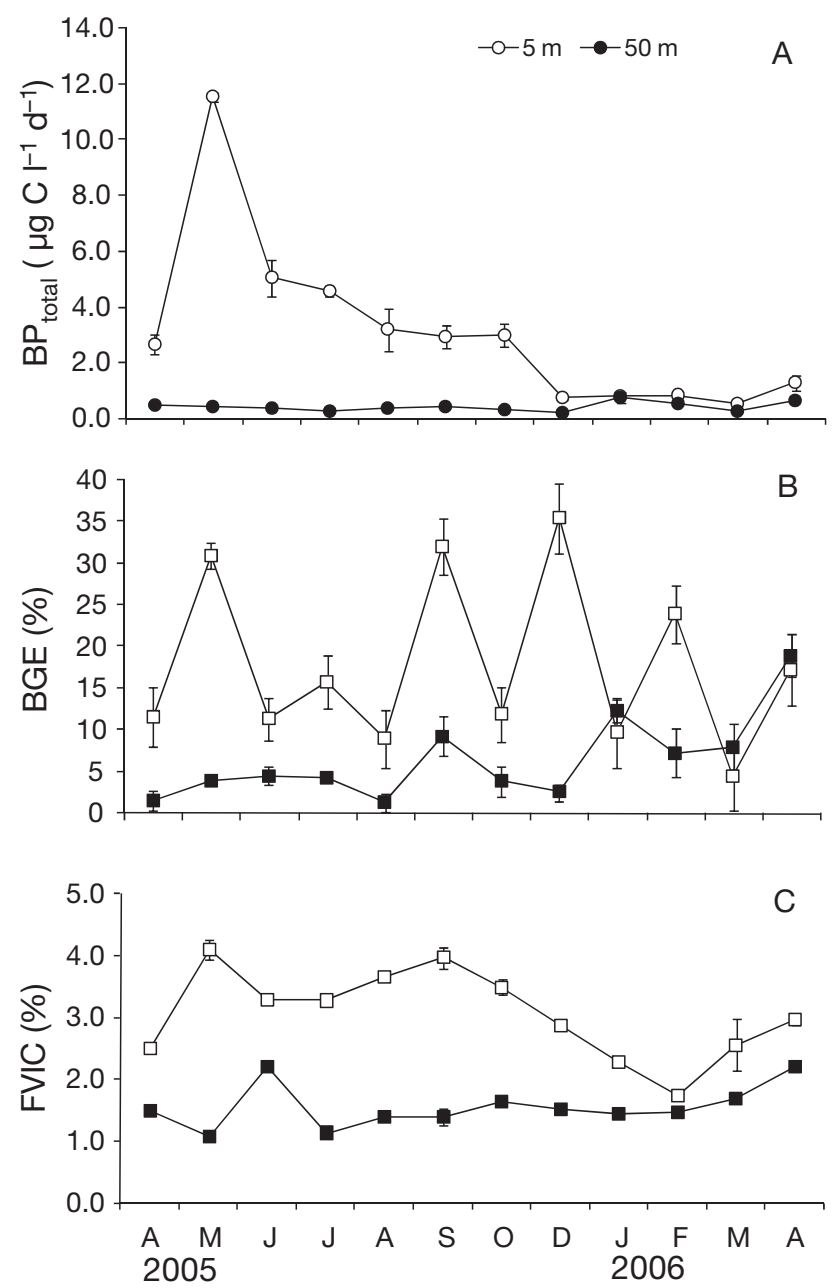

Fig. 2. Seasonal variations in (A) total bacterial production $\left(\mathrm{BP}_{\text {total }}\right),(\mathrm{B})$ bacterial growth efficiency $(\mathrm{BGE})$, and $(\mathrm{C})$ frequency of visibly infected cells (FVIC) at depths of 5 and $50 \mathrm{~m}$ at a pelagic site of Lake Biwa. Error bars indicate SEM $(n=3)$ 
ratios were $7.4 \pm 1.6$ and $8.6 \pm 1.1$ for depths of 5 and $50 \mathrm{~m}$, respectively (Table 1 ). The average viral abundance to bacterial abundance ratio during the mixing period was $8.7 \pm 1.3$.

During the stratification period, HNF abundance at a depth of $5 \mathrm{~m}$ (range $1.4 \times 10^{6}$ to $3.0 \times 10^{6}$ cells $\mathrm{l}^{-1}$; mean \pm SD $2.2 \times 10^{6} \pm 0.6 \times 10^{6}$ cells $1^{-1}$ ) was about 2 -fold greater on average than that at a depth of $50 \mathrm{~m}$ (range $0.6 \times 10^{6}$ to $1.1 \times 10^{6}$ cells $^{-1}$; mean \pm SD $0.8 \times 10^{6} \pm 0.2 \times$ $10^{6}$ cells $\mathrm{l}^{-1}$; Fig. 1C, Table 1). This tendency was also observed during the mixing period (Fig. 1C), yielding a

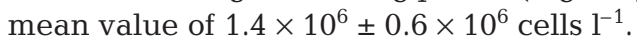

\section{$\mathrm{BP}, \mathrm{BR}$, growth rate, and $\mathrm{BGE}$}

BP determined for the total fraction exhibited strong vertical and seasonal variability (Fig. 2A). At a depth of $5 \mathrm{~m}$, the highest BP in May $\left(11.5 \mu \mathrm{g} \mathrm{C}^{-1} \mathrm{~d}^{-1}\right)$ was 16 fold greater than the lowest BP obtained in December $\left(0.7 \mu \mathrm{g} \mathrm{C}^{-1} \mathrm{~d}^{-1}\right)$; the mean value during the stratifica-

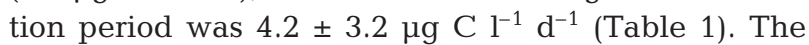
peak BP in May coincided with that of viral abundance (Figs. 1A \& 2A). In the deeper layer $(50 \mathrm{~m})$, BP varied

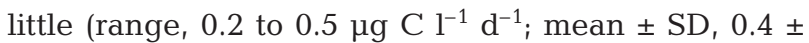
$0.1 \mu \mathrm{g} \mathrm{C}^{-1} \mathrm{~d}^{-1}$ ) during the stratification period. Mean BP pooled for the 2 depth layers during the mixing period was $0.7 \pm 0.3 \mu \mathrm{g} \mathrm{C}^{-1} \mathrm{~d}^{-1}$ (Table 1). BR at $5 \mathrm{~m}$ $\left(\right.$ mean $\pm \mathrm{SD} 31.7 \pm 18.2 \mu \mathrm{g} \mathrm{O}_{2} \mathrm{l}^{-1} \mathrm{~d}^{-1}$ ) tended to be higher than that at $50 \mathrm{~m}$ (mean $\pm \mathrm{SD} 18.9 \pm 8.2 \mu \mathrm{g} \mathrm{O}_{2} \mathrm{l}^{-1}$ $\mathrm{d}^{-1}$ ) during the stratification period, although mean values did not differ significantly $(p>0.05)$ between the 2 layers. Mean BR during the mixing period was $9.4 \pm 3.0 \mu \mathrm{g} \mathrm{O}_{2} \mathrm{l}^{-1} \mathrm{~d}^{-1}$ (Table 1).

We calculated bacterial metabolic parameters, including growth rate (production rate of bacterial cells/bacterial abundance) and BGE (Fig. 2B), using the bacterial variables data. During the stratification period, bacterial growth rate at $5 \mathrm{~m}$ (mean \pm SD $0.04 \pm$ $0.03 \mathrm{~d}^{-1}$ ) was significantly $(\mathrm{p}<0.05)$ higher $(4$-fold $)$ than that at $50 \mathrm{~m}\left(\right.$ mean \pm SD $\left.0.01 \pm 0.01 \mathrm{~d}^{-1}\right)$, although the value was low (mean $0.01 \pm 0.001 \mathrm{~d}^{-1}$ ) in both layers during the mixing period (Table 1). During the stratification period, average BGE at a depth of $5 \mathrm{~m}$ $($ mean \pm SD $19.7 \pm 11.1 \%)$ was significantly $(\mathrm{p}<0.05)$ greater than that at a depth of $50 \mathrm{~m}$ (mean \pm SD $3.9 \pm$ $2.5 \%$; Table 1). During the mixing period, mean BGE was $12.8 \pm 6.7 \%$ (Table 1 ).
Table 1. Summary of the viral and bacterial variables determined in the north basin of Lake Biwa. The data were divided into 3 categories: the upper layer $(5 \mathrm{~m})$ during the stratification period $(\mathrm{n}=8)$, the deeper layer $(50 \mathrm{~m})$ during the stratification period $(n=8)$, and both layers during the mixing period $(n=8)$. Stratification and mixing periods were April to December 2005 and January to April 2006, respectively. Errors are \pm SD. For statistical comparisons, 1-way ANOVA was used, except for underlined variables, for which Kruskal-Wallis 1-way ANOVA on ranks was used because requirements for ANOVA were not met. Values with different superscripted letters are significantly $(p<0.05)$ different. $\mathrm{BA}=$ bacterial abundance, FVIC $=$ frequency of visibly infected cells, $\mathrm{HNF}=$ heterotrophic nanoflagellate, $\mathrm{VA}=$ viral abundance

\begin{tabular}{|c|c|c|c|}
\hline Variable & $\begin{array}{c}\text { Stratification } \\
\qquad(5 \mathrm{~m})\end{array}$ & $\begin{array}{l}\text { Stratification } \\
\quad(50 \mathrm{~m})\end{array}$ & $\begin{array}{c}\text { Mixing } \\
(5 \text { and } 50 \mathrm{~m})\end{array}$ \\
\hline VA $\left(\times 10^{10}\right.$ viruses $\left.l^{-1}\right)$ & $3.0 \pm 0.7^{\mathrm{a}}$ & $1.7 \pm 0.5^{b}$ & $2.1 \pm 0.6^{b}$ \\
\hline$\underline{\mathrm{BA}}\left(\times 10^{9}\right.$ cells $\left.^{-1}\right)$ & $4.3 \pm 1.5^{\mathrm{a}}$ & $1.9 \pm 0.6^{\mathrm{b}}$ & $2.3 \pm 0.5^{\mathrm{b}}$ \\
\hline VA:BA ratio & $7.4 \pm 1.6^{\mathrm{a}}$ & $8.6 \pm 1.1^{\mathrm{a}}$ & $8.7 \pm 1.3^{\mathrm{a}}$ \\
\hline $\begin{array}{l}\text { HNF abundance } \\
\left(\times 10^{6} \text { cells } ~^{-1}\right)\end{array}$ & $2.2 \pm 0.6^{\mathrm{a}}$ & $0.8 \pm 0.2^{b}$ & $1.4 \pm 0.6^{\mathrm{a}, \mathrm{b}}$ \\
\hline$\frac{\text { Total bacterial production }}{\left(\mu \mathrm{g} \mathrm{C} \mathrm{l}^{-1} \mathrm{~d}^{-1}\right)}$ & $4.2 \pm 3.2^{\mathrm{a}}$ & $0.4 \pm 0.1^{\mathrm{b}}$ & $0.7 \pm 0.3^{\mathrm{a}, \mathrm{b}}$ \\
\hline$\frac{\text { Bacterial respiration }}{\left(\mu \mathrm{O}_{2} \mathrm{l}^{-1} \mathrm{~d}^{-1}\right)}$ & $31.7 \pm 18.2^{\mathrm{a}}$ & $18.9 \pm 8.2^{\mathrm{a}, \mathrm{b}}$ & $9.4 \pm 3.0^{\mathrm{b}}$ \\
\hline Bacterial growth rate $\left(\mathrm{d}^{-1}\right)$ & $0.04 \pm 0.03^{\mathrm{a}}$ & $0.01 \pm 0.01^{\mathrm{b}}$ & $0 . .01 \pm 0.001^{\mathrm{a}, \mathrm{b}}$ \\
\hline $\begin{array}{l}\text { Bacterial gross growth } \\
\text { efficiency }(\%)\end{array}$ & $19.7 \pm 11.1^{\mathrm{a}}$ & $3.9 \pm 2.5^{\mathrm{b}}$ & $12.8 \pm 6.7^{\mathrm{a}, \mathrm{b}}$ \\
\hline FVIC $(\%)$ & $3.4 \pm 0.5^{\mathrm{a}}$ & $1.5 \pm 0.4^{\mathrm{b}}$ & $2.1 \pm 0.6^{\mathrm{c}}$ \\
\hline Burst size (viruses cell ${ }^{-1}$ ) & $22 \pm 8^{\mathrm{a}}$ & $32 \pm 13^{a}$ & $30 \pm 11^{a}$ \\
\hline
\end{tabular}

\section{FVIC and burst size}

During the stratification period, FVIC at a depth of $5 \mathrm{~m}$ varied from 1.8 to $4.1 \%$ with a mean $( \pm \mathrm{SD})$ of $3.4 \pm$ $0.5 \%$, which was significantly $(\mathrm{p}<$ $0.001)$ greater (2-fold) than the corresponding value at a depth of $50 \mathrm{~m}$ (range 1.1 to $2.2 \%$; mean \pm SD $1.5 \pm$ $0.4 \%$; Fig. 2C, Table 1). During the mixing period, the mean FVIC ( \pm SD) was $2.1 \pm 0.6 \%$ (range 1.5 to $3 \%$ ). During the stratification period, burst size (mean number of intracellular viruses observed per infected cell) varied from 5 to 200 . Average values were $28 \pm 8$ and $32 \pm 13$ at depths of 5 and $50 \mathrm{~m}$, respectively, with no significant ( $p$ > 0.05 ) difference between the 2 layers. The corresponding value averaged for both layers during the mixing period was $30 \pm 11$ (Table 1). There was no clear seasonal trend in burst size variation.

Fig. 3 shows transmission electron micrographs of viral-infected bacterial cells, emphasizing large variability in burst size and morphology. The head size of intracellular viruses ranged 


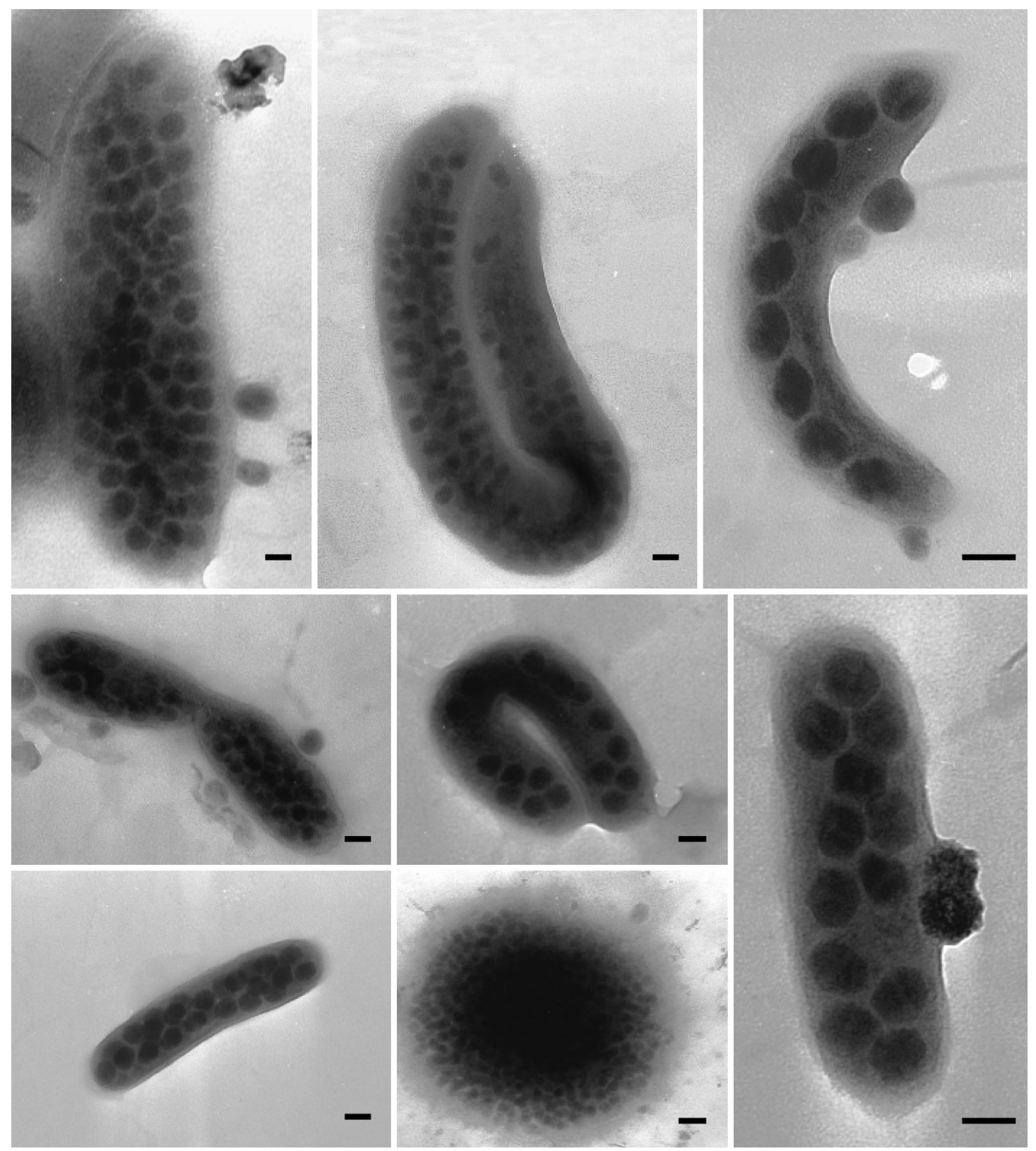

Fig. 3. Transmission electron micrographs of bacterial cells infected by viruses. Scale bars $=100 \mathrm{~nm}$

from 50 to $130 \mathrm{~nm}$ (mostly within a size range of 90 to $130 \mathrm{~nm})$.

\section{Bacterial mortality}

FMVL was higher at $5 \mathrm{~m}$ (mean $\pm \mathrm{SD} 52.7 \pm 16.2 \%)$ than at $50 \mathrm{~m}$ (mean $\pm \mathrm{SD} 13.6 \pm 5.2 \%$ ) depth during the stratification period. During the mixing period, mean FMVL $( \pm$ SD) was $23 \pm 10 \%$ (Table 2 ). During the stratification period, $\mathrm{HNF}$ grazing rate at $5 \mathrm{~m}$ (mean $\pm \mathrm{SD}$
$5.0 \times 10^{7} \pm 4.3 \times 10^{7}$ cells $\mathrm{l}^{-1} \mathrm{~d}^{-1}$ ) was about 1 order of magnitude higher than the corresponding value at $50 \mathrm{~m}$ (mean $\pm \mathrm{SD} 0.4 \times 10^{7} \pm 0.1 \times 10^{7}$ cells $\mathrm{l}^{-1} \mathrm{~d}^{-1}$; Table 2), and the difference between the 2 layers was significant $(p<0.001)$. The corresponding value for the mixing period was $0.6 \times 10^{7} \pm 0.3 \times 10^{7}$ cells $\mathrm{l}^{-1} \mathrm{~d}^{-1}$ (Table 2). Percentages of BP consumed by HNF (bacterivory) were estimated to be $39.7 \pm 31.3 \%$ and $26.5 \pm$ $11.0 \%$ for the upper and deeper layers, respectively, during the stratification period, whereas HNF grazing accounted for $23.2 \pm 6.9 \%$ of $\mathrm{BP}$ during the mixing 
Table 2. Summary of the frequency of bacterial mortality due to viral lysis (FMVL), heterotrophic nanoflagellate (HNF) grazing rate, percentage of bacterial production consumed by HNF (bacterivory), and the ratio of FMVL to bacterivory determined in the north basin of Lake Biwa. See Table 1 for explanations of sampling periods. Errors are \pm SD $(n=8)$. For statistical comparisons, Kruskal-Wallis 1-way ANOVA on ranks were used because requirements for ANOVA were not met. Values with different superscripted letters are significantly $(\mathrm{p}<0.05)$ different

\begin{tabular}{|lccc|}
\hline Variable & $\begin{array}{c}\text { Stratification } \\
(5 \mathrm{~m})\end{array}$ & $\begin{array}{c}\text { Stratification } \\
(50 \mathrm{~m})\end{array}$ & $\begin{array}{c}\text { Mixing } \\
(5 \text { and } 50 \mathrm{~m})\end{array}$ \\
\hline $\begin{array}{l}\text { FMVL (\% of bacterial } \\
\text { production) }\end{array}$ & $52.7 \pm 16.2^{\mathrm{a}}$ & $13.6 \pm 5.2^{\mathrm{b}}$ & $23.0 \pm 10.0^{\mathrm{a}, \mathrm{b}}$ \\
$\begin{array}{l}\text { HNF grazing rate } \\
\left(\times 10^{7} \text { cells 1 }{ }^{-1} \mathrm{~d}^{-1}\right)\end{array}$ & $5.0 \pm 4.3^{\mathrm{a}}$ & $0.4 \pm 0.1^{\mathrm{b}}$ & $0.6 \pm 0.3^{\mathrm{b}}$ \\
$\begin{array}{l}\text { Bacterivory (\% of } \\
\text { bacterial production) } \\
\text { FMVL:bacterivory ratio }\end{array}$ & $39.7 \pm 31.3^{\mathrm{a}}$ & $26.5 \pm 11.0^{\mathrm{a}}$ & $23.2 \pm 6.9^{\mathrm{a}}$ \\
\hline
\end{tabular}

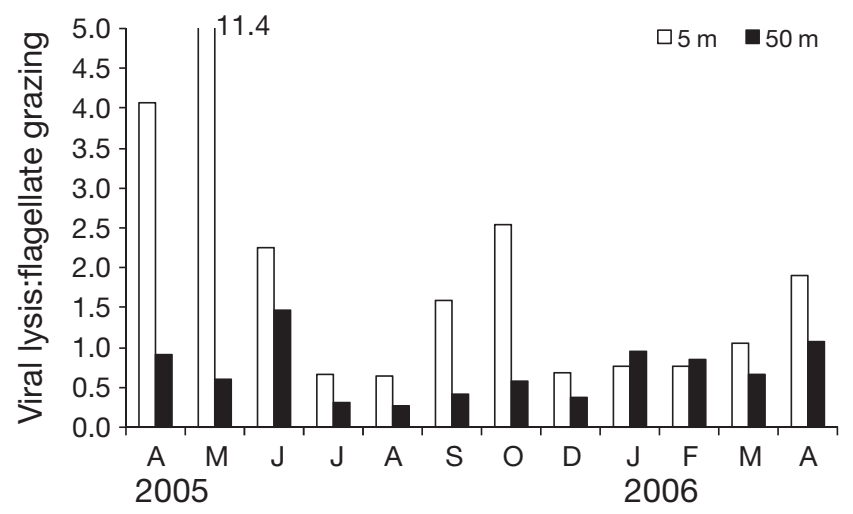

Fig. 4. Seasonal variations in the ratio of viral-induced mortality to heterotrophic nanoflagellate (HNF)-grazing-induced mortality of bacteria at depths of 5 and $50 \mathrm{~m}$ at a pelagic site of Lake Biwa

period (Table 2). During the stratification period, the mortality induced by viruses exceeded that due to grazing (FMVL:bacterivory ratio $3.0 \pm 3.6$ ) in the upper layer, with the highest ratio of 11.4 in May (Fig. 4), whereas the reverse was true (FMVL:bacterivory ratio $0.6 \pm 0.4$ ) in the deep layer. During the mixing period, the extent of mortality caused by viruses was equivalent to the mortality caused by HNF (FMVL:bacterivory ratio $1.0 \pm 0.4$; Table 2 ).

\section{Correlations}

Table 3 summarizes the results of Pearson's correlation analyses between viral parameters (viral abundance, FVIC, and burst size) and environmental variables. Viral abundance was strongly and positively correlated with bacterial abundance $(\mathrm{r}=0.88, \mathrm{p}<0.001)$ and BP $(\mathrm{r}=0.77$, $\mathrm{p}<0.001)$. FVIC was strongly and positively correlated with BP $(r=0.87, \mathrm{p}<$ $0.001)$ and HNF abundance $(r=0.81$, $\mathrm{p}<0.001)$. We found no significant correlation between burst size and environmental variables except that there was a weak negative correlation with temperature $(r=-0.49, \mathrm{p}<0.05)$. Forward stepwise multiple regression analysis was conducted to select variables accounting for variation in viral abundance and FVIC. The results indicated that bacterial abundance was a strong predictor of viral abundance, accounting for $76 \%$ of the variation; the regression equation (Model II) that relates bacterial abundance to viral abundance is as follows: viral abundance $=5.74+5.83 \times$ bacterial abundance (adjusted $\mathrm{r}^{2}=$ 0.755, $\mathrm{p}<0.001, \mathrm{n}=24$; Fig. 5). Other variables listed in Table 3 did not add significantly to the ability of the equation to predict viral abundance. Bacterial cellular production and the abundance of HNF were selected as significant $(p<0.05)$ predictor variables that explained, in a linear combination, $81 \%$ of the variation in FVIC: FVIC $=0.92+1.19 \times \mathrm{BP}+0.50 \times \mathrm{HNF}$ abundance (adjusted $\mathrm{r}^{2}=0.811, \mathrm{p}<0.001, \mathrm{n}=24$ ).

\section{DISCUSSION}

Despite the increasing recognition that viruses are the major agent of bacterial mortality, the incorporation of viral-mediated processes into biogeochemical models of aquatic systems has been largely hampered

Table 3. Pearson's correlation coefficient (r) of viral parameters and environmental variables $(\mathrm{n}=24) .{ }^{*} \mathrm{p}<0.05,{ }^{* *} \mathrm{p}<$ $0.01,{ }^{* * *} p<0.001$. FVIC $=$ frequency of visibly infected cells, $\mathrm{HNF}=$ heterotrophic nanoflagellate, $\mathrm{ns}=$ not significant

\begin{tabular}{|lclc|}
\hline Variable & $\begin{array}{c}\text { Viral } \\
\text { abundance }\end{array}$ & FVIC & $\begin{array}{c}\text { Burst } \\
\text { size }\end{array}$ \\
\hline Temperature & $0.67^{* * *}$ & $0.79^{* * *}$ & $-0.49^{*}$ \\
Bacterial abundance $_{\text {Total bacterial production }}{ }^{\text {a }}$ & $0.88^{* * *}$ & $0.77^{* * *}$ & $\mathrm{~ns}$ \\
Bacterial respiration $^{* * *}$ & $0.87^{* * *}$ & $\mathrm{~ns}$ \\
Bacterial growth efficiency & $0.59^{* *}$ & $0.47^{*}$ & $\mathrm{~ns}$ \\
Bacterial growth rate & $0.59^{* *}$ & $0.68^{* * *}$ & $\mathrm{~ns}$ \\
HNF abundance & $0.65^{* * *}$ & $0.81^{* * *}$ & $\mathrm{~ns}$ \\
a Correlation analysis was conducted after log transforma- \\
tion to reduce high variance for larger values \\
\hline
\end{tabular}




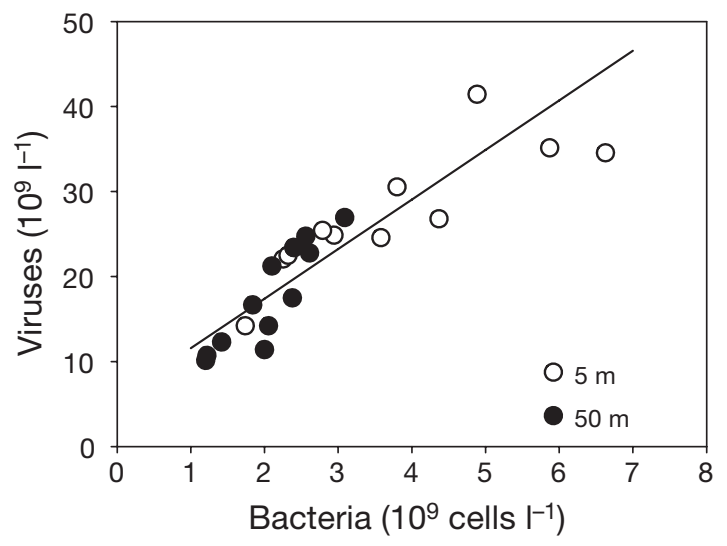

Fig. 5. Relationship between bacterial abundance and viral abundance at a pelagic site of Lake Biwa. The Model II regression line for all the plots is shown: Viral abundance $=$ $5.74+5.83 \times$ Bacterial abundance (adjusted $\mathrm{r}^{2}=0.755, \mathrm{p}<$ $0.001, \mathrm{n}=24$ )

by inadequacies in knowledge regarding factors that control variation in viral parameters (abundance, infectivity, and viral-induced mortality of bacteria), especially in freshwater lakes (Gobler et al. 2008, Pradeep Ram et al. 2009). Data are also scarce regarding the relative importance of viral lysis and HNF grazing as mortality forces of bacteria. Our seasonal data on viral and bacterial variables collected in the upper (euphotic) and deeper (aphotic) layers of a large freshwater lake reveal some notable features regarding potential links between viral and other microbial components.

In previous work conducted in Lake Biwa, Honjo et al. (2007) found complex relationships between viral abundance and environmental variables, suggesting that chlorophyll (chl) a (rather than total bacterial abundance) was the best predictor of viral abundance. Close couplings between phytoplankton and viruses have been also noted in other lakes. Maranger \& Bird (1995) found that viral abundance in Canadian lakes was positively correlated with chl $a$, but not with bacterial abundance; the authors interpreted these results as indicating that cyanophages largely contribute to total viral abundance, although other possibilities were not excluded. More recently, Clasen et al. (2008) have reported cyanobacteria and chl a to be significant predictor variables of viral abundances in 16 lakes in central and western North America. In contrast, the present study data suggest a tight coupling between bacteria and viruses: a large fraction (76\%) of the variation in viral abundance was explained by bacterial abundance alone. Although strong correlations between bacterial and viral abundances have been reported in some oceanic regions (reviewed by Weinbauer 2004), relatively few studies have found such relationships in freshwater lakes (cf. Peduzzi \& Luef 2009, Pradeep Ram et al. 2005, 2009). We note that the linear relationship between viral and bacterial abundance in Lake Biwa holds not only for the euphotic zone but also for the aphotic zone, where the role of photosynthetic organisms as viral hosts should be minimal. In addition, the relationship is apparently consistent for both layers (Fig. 5), suggesting that the majority of viruses in both the upper and deeper layers of Lake Biwa are coupled with bacteria. However, temporal resolutions of our data (sampling with a monthly interval) were probably too low to capture temporal dynamics of cyanophages and their hosts (picoplanktonic cyanobacteria display seasonal peaks during warm seasons in Lake Biwa; Nagata 1986, Maeda et al. 1992). Thus, we do not exclude the possibility that cyanophages are important components of viral communities in Lake Biwa, as suggested in other lakes (Maranger \& Bird 1995, Clasen et al. 2008). The difference in results of correlation analyses between Honjo et al. (2007) and the present study might be explained by a large variation, over seasons and years, in the mode of virus-host couplings in Lake Biwa.

The notion that viruses are tightly coupled with bacteria in the Lake Biwa water column was supported by a strong positive correlation between BP and FVIC, indicating that more viruses are produced when BP is high. This result is consistent with previous knowledge that lytic infection increases with increasing host activity (Weinbauer et al. 2003a, Colombet et al. 2006, Motegi \& Nagata 2007). In addition to BP, our statistical analysis indicated that HNF abundance is a strong predictor of FVIC in Lake Biwa. The linear combination of BP and HNF abundance explained a substantial fraction $(81 \%)$ of FVIC variation. Consistent with our results, the FVIC tended to be high in the Rimov Reservoir (South Bohemia, Czech Republic) when HNF abundance was high (Šimek et al. 2001, Weinbauer et al. 2003b). These data, obtained by the present study and previous studies, might suggest that viral infectivity increases with increasing grazing pressure by HNF. Under high grazing pressure, grazing-resistant forms of bacteria (e.g. filamentous bacteria) become abundant in freshwater-lake bacterial communities (Šimek et al. 2001, Nishimura \& Nagata 2007). Some studies have reported that grazing-resistant forms of bacteria are more susceptible to viral infection, presumably because of a trade-off between grazing resistance and viral resistance (Weinbauer et al. 2007, Pradeep Ram \& Sime-Ngando 2008).

The positive correlation between FVIC and BGE that we found in Lake Biwa does not agree with the notion that viral-induced mortality reduces BGE via acceleration of the cyclic flow of carbon through the bacteria $\rightarrow$ viruses $\rightarrow$ DOM $\rightarrow$ bacteria pathway (viral shunt; 
Fuhrman 1999, Wilhelm \& Suttle 1999, Miki et al. 2008, Motegi et al. 2009). In the present study, BGE was consistently low in deeper layers, where there is low substrate concentration and substantial depletion in nitrogen and phosphorus in DOM (Kim et al. 2006). This suggests that substrate condition (Lopez-Urrutia \& Moran 2007) rather than viral shunt was a major factor affecting BGE in the deeper layer of Lake Biwa.

In the present study, viral lysis was estimated from FVIC and HNF grazing from cell counts and assumed clearance rates. Methodological problems inherent to these approaches should be commented on. With regard to the determination of viral-mediated bacterial mortality, there is a source of bias associated with the empirical models converting FVIC to FMVL. In the present study, we used a model proposed by Weinbauer et al. (2002) (FVIC to FIC conversion) and Binder (1999) (FIC to FMVL conversion). Weinbauer et al. (2002) empirically derived the model on the basis of the comparison between FIC (obtained from a virus dilution approach) and FVIC. Although the TEMbased derivation of FVIC, combined with the above models, has been increasingly used in recent studies conducted in freshwater lakes (Jacquet et al. 2005, Pradeep Ram et al. 2009), it should be noted that there are several critical assumptions underlying the derivation of the models. These assumptions include that the bacteria-virus system is in a steady state and that grazers do not discriminate between infected and uninfected hosts (Binder 1999). It is likely that the parameters of the model vary depending on environmental conditions, although the extent and cause of this variability remain unclear. Because the applicability of these parameters in Lake Biwa has yet to be validated, the estimates of viral-induced mortality that we report in the present paper should be interpreted with caution.

For the derivation of HNF grazing, it was assumed that a fixed volume-specific clearance rate (Fenchel 1982) can be applied to the whole samples regardless of depth layers and seasons. In addition, it was assumed that the average cell volume obtained in previous work (Nagata 1987a, 1988) was applicable to each depth layer. These assumptions may deviate from reality given potentially large variations in cell size, community composition, and physiological state of HNF in Lake Biwa. Nonetheless, the cell-specific clearance rates were 0.8 to $6.2 \mathrm{nl}$ ind. ${ }^{-1} \mathrm{~h}^{-1}$, which are generally within the range of HNF clearance rates obtained for freshwater communities (Sanders et al. 1989). Thus, we consider that our results could be regarded as first-order estimates of bacterial mortality due to HNF grazing in Lake Biwa.

Our results indicated that 53 and $14 \%$ of $\mathrm{BP}$ was destroyed by viruses in the upper and deeper layers, respectively, during the stratification period. The corresponding value for the mixing period was $23 \%$. These values are higher than (upper layer), close to (circulation period), and lower than (deeper layer) the average FMVL (20\%) derived from cross-system compilations of available data (reviewed in Weinbauer 2004, Sime-Ngando \& Colombet 2009). Comparisons of the extent of viral lysis and grazing pressure posed by HNF indicated that the relative importance of these 2 mortality forces differed between the upper and deeper layers during the stratification period. On average, mortality due to viral lysis was much higher (3-fold) than that ascribed to grazing in the upper layer. Conversely, in the deeper layer, grazinginduced bacterial mortality was 1.7 -fold greater than viral-induced mortality. This vertical pattern differs from previous results obtained in other stratified water bodies; those studies found that grazing generally dominates in surface waters, whereas viral lysis is more prominent in deeper waters (Weinbauer \& Höfle 1998, Bettarel et al. 2004, Colombet et al. 2006). In Lake Biwa, dissolved oxygen concentration was high (>5 $\mathrm{mg} \mathrm{l}^{-1}$ ) even at a depth of $50 \mathrm{~m}$ throughout the year, meaning that HNF activity was minimally inhibited by oxygen depletion (Weinbauer \& Höfle 1998). Viral production might be suppressed in deeper layers of Lake Biwa because of low bacterial activity (as indicated by the low bacterial growth rate and BGE) and depletion in phosphorus (soluble reactive phosphorus [SRP] concentrations in the Lake Biwa hypolimnion are $<0.1 \mu \mathrm{mol} \mathrm{l}^{-1}$, except in the benthic boundary layer; Kim et al. 2006), as suggested in other aquatic environments (Peduzzi \& Schiemer 2004, Motegi et al. 2009). These factors might explain high HNF grazing relative to viral lysis in the deeper layer during the stratification period in Lake Biwa.

The sum of viral lysis and HNF grazing accounted for $92 \%$ of BP in the upper layer during the stratification period, implying that BP is generally in balance with losses from the 2 mortality forces examined. In this layer, high mortality due to viruses (53\%) indicates that BP is intensively recycled via the viral shunt, facilitating efficient regeneration of carbon, nitrogen, and phosphorus (Fuhrman 1999, Weinbauer 2004). In contrast, viral lysis and HNF grazing collectively accounted for only $40 \%$ of BP in the deeper layer during the stratification period (Table 2). The corresponding value was also low (43\%) during the circulation period. Given that bacterial abundance varied little in the deep layer during the study period (Fig. 1), there appear to be loss factor(s) other than viral lysis and HNF grazing. Potential factors may include sinking loss due to large particle adsorption (Proctor \& Fuhrman 1991) and metazoan grazing (Nagata \& Okamoto 1988). 


\section{CONCLUSIONS}

The present study provided evidence in support of the notion that virus-bacterium couplings are tight and exert significant influences on microbial food-web dynamics in a thermally stratified, large freshwater lake (Lake Biwa). The present results agree with the growing consensus that viruses are critical components of freshwater ecosystems (Middelboe et al. 2008, Wilhelm \& Matteson 2008). Our estimates, indicating high viral-mediated bacterial mortality especially in the upper layer, indicate that a significant fraction of $\mathrm{BP}$ is recycled in the bacterium-virus-DOM loop, contributing to carbon and nutrient cycling of lakes (Pradeep Ram et al. 2009). The present results also suggest the need for further studies regarding viral control of bacterial diversity in lakes (Weinbauer \& Rassoulzadegan 2004). However, there are uncertainties in conversion factors and the models involved in the estimations of growth and mortality parameters of bacteria-virus-HNF systems. Unambiguous resolutions of biogeochemical cycles mediated by viruses in freshwater lakes require future studies that critically assess the methods of viral-related rate measurements.

Acknowledgements. We thank K. Koitabashi, T. Miyano, and T. Yokokawa for their assistance during field sampling. We also thank Dr. T. Sime-Ngando (Université Blaise Pascal, Aubiére, France) for valuable discussions and constructive comments. The present study was supported by the 21st Century COE program of Kyoto University (A14), JSPS grants (18651007, 17201004), and the Global Environment Research Fund (Fa-084) of the Ministry of the Environment, Japan awarded to T.N. A.S.P.R. was supported by a JSPS postdoctoral research fellowship.

\section{LITERATURE CITED}

Bettarel Y, Sime-Ngando T, Amblard C, Dolan J (2004) Viral activity in two contrasting lake ecosystems. Appl Environ Microbiol 70:2941-2951

Binder B (1999) Reconsidering the relationship between virally induced bacterial mortality and frequency of infected cells. Aquat Microb Ecol 18:207-215

Breitbart M, Rohwer F (2005) Here a virus, there a virus, everywhere the same virus? Trends Microbiol 13:278-284

Brum JR, Steward GF, Jiang SC, Jellison R (2005) Spatial and temporal variability of prokaryotes, viruses, and viral infections of prokaryotes in an alkaline, hypersaline lake. Aquat Microb Ecol 41:247-260

Carignan R, Blais AM, Vis C (1998) Measurement of primary production and community respiration in oligotrophic lakes using the Winkler method. Can J Fish Aquat Sci 55: 1078-1084

Choi JW, Stoecker DK (1989) Effects of fixation on cell volume of marine planktonic protozoa. Appl Environ Microbiol 55: 1761-1765

Clasen JL, Brigden SM, Payet JP, Suttle CA (2008) Evidence that viral abundance across oceans and lakes is driven by different biological factors. Freshw Biol 53:1090-1100
Colombet J, Sime-Ngando T, Cauchie HM, Fonty G, Hoffmann L, Demeure G (2006) Depth-related gradients of viral activity in Lake Pavin. Appl Environ Microbiol 72: 4440-4445

Fenchel T (1982) Ecology of heterotrophic microflagellates. II. Bioenergetics and growth. Mar Ecol Prog Ser 8:225-231

$>$ Fuhrman JA (1999) Marine viruses and their biogeochemical and ecological effects. Nature 399:541-548

Fuhrman JA, Noble RT (1995) Viruses and protists cause similar mortality in coastal seawater. Limnol Oceanogr 40: 1236-1242

Gobler CJ, Davis TW, Deonarine SN, Saxton MA, Lavrentyev PJ, Jochem FJ, Wilhelm SW (2008) Grazing and virusinduced mortality of microbial populations before and during the onset of annual hypoxia in Lake Erie. Aquat Microb Ecol 51:117-128

Honjo M, Matsui K, Ishii N, Nakanishi M, Kawabata Z (2007) Viral abundance and its related factors in a stratified lake. Fundam Appl Limnol (Arch Hydrobiol) 168:105-112

Jacquet S, Domaizon I, Personnic S, Pradeep Ram AS, Heldal M, Duhamel S, Sime-Ngando T (2005) Estimates of protozoan- and viral-mediated mortality of bacterioplankton in Lake Bourget (France). Freshw Biol 50:627-645

Jørgensen NOG (1992) Incorporation of $\left[{ }^{3} \mathrm{H}\right]$ leucine and $\left[{ }^{3} \mathrm{H}\right]$ valine into protein of freshwater bacteria: uptake kinetics and intracellular isotope dilution. Appl Environ Microbiol 58:3638-3646

Kim C, Nishimura Y, Nagata T (2006) Role of dissolved organic matter in the hypolimnetic mineralization of carbon and nitrogen in a large monomictic lake. Limnol Oceanogr 51:70-78

Kirchman DL (2001) Measuring bacterial biomass production and growth rates from leucine incorporation in natural aquatic environment. In: Paul JH (ed) Methods in microbiology, Vol 30. Academic Press, San Diego, CA, p 227-237

> Kirchman DL, K'nees E, Hodson RE (1985) Leucine incorporation and its potential as a measure of protein synthesis by bacteria in natural aquatic systems. Appl Environ Microbiol 49:599-607

Kirchman DL, Rich JH, Barber RT (1995) Biomass and biomass production of heterotrophic bacteria along $140^{\circ} \mathrm{W}$ in the equatorial Pacific: effect of temperature on the microbial loop. Deep Sea Res II 42:603-619

Lopez-Urrutia A, Moran XAG (2007) Resource limitation of bacterial production distorts the temperature dependence of oceanic carbon cycling. Ecology 88:817-822

Maeda H, Kawai A, Tilzer MM (1992) The water bloom of cyanobacterial picoplankton in Lake Biwa, Japan. Hydrobiologia 248:93-102

Maranger R, Bird DF (1995) Viral abundance in aquatic systems: a comparison between marine and fresh waters. Mar Ecol Prog Ser 121:217-226

Middelboe M, Jorgensen NOG, Kroer N (1996) Effects of viruses on nutrient turnover and growth efficiency of noninfected marine bacterioplankton. Appl Environ Microbiol 62:1991-1997

> Middelboe M, Jacquet S, Weinbauer M (2008) Viruses in freshwater ecosystems: an introduction to the exploration of viruses in new aquatic habitats. Freshw Biol 53:1069-1075

Miki T, Nakazawa T, Yokokawa T, Nagata T (2008) Functional consequences of viral impacts on bacterial communities: a food-web model analysis. Freshw Biol 53: $1142-1153$

> Motegi C, Nagata T (2007) Enhancement of viral production by addition of nitrogen or nitrogen plus carbon in subtropical surface waters of the South Pacific. Aquat Microb Ecol 48:27-34 
Motegi C, Nagata T, Miki T, Weinbauer MG, Legendre L, Rassoulzadegan F (2009) Viral control of bacterial growth efficiency in marine pelagic environments. Limnol Oceanogr 54:1901-1910

Nagata T (1986) The seasonal abundance and vertical distribution of the $<3 \mu \mathrm{m}$ phytoplankton in the north basin of Lake Biwa. Ecol Res 1:207-221

Nagata T (1987a) Ecological studies on planktonic microbes in Lake Biwa: from a trophic dynamic viewpoint. Doctoral dissertation, Kyoto University

$>$ Nagata T (1987b) Production rate of planktonic bacteria in the north basin of Lake Biwa. Appl Environ Microbiol 53: $2872-2882$

Nagata T (1988) The microflagellate picoplankton food linkage in the water column of Lake Biwa. Limnol Oceanogr 33:504-517

Nagata T, Kirchman DL (1990) Filtration-induced release of dissolved free amino acids: application to cultures of marine protozoa. Mar Ecol Prog Ser 68:1-5

Nagata T, Okamoto K (1988) Filtering rates on natural bacteria by Daphnia longispina and Eodiaptomus japonicus in Lake Biwa. J Plankton Res 10:835-850

Nishimura Y, Nagata T (2007) Alphaproteobacterial dominance in a large mesotrophic lake (Lake Biwa, Japan). Aquat Microb Ecol 48:231-240

Nishimura Y, Kim C, Nagata T (2005) Vertical and seasonal variations of bacterioplankton subgroups with different nucleic acid content: possible regulation by phosphorus. Appl Environ Microbiol 71:5828-5836

Noble RT, Fuhrman JA (1998) Use of SYBR Green I for rapid epifluorescence counts of marine viruses and bacteria. Aquat Microb Ecol 14:113-118

Pace ML, Cole JJ (1996) Regulation of bacteria by resources and predation tested in whole-lake experiments. Limnol Oceanogr 41:1448-1460

Peduzzi P, Luef B (2009) Significance of viruses for inland aquatic ecosystems. In: Likens GE (ed) Encyclopedia of inland waters, Vol 3. Elsevier, Oxford, p 279-294

$>$ Peduzzi P, Schiemer F (2004) Bacteria and viruses in the water column of tropical freshwater reservoirs. Environ Microbiol 6:707-715

Pradeep Ram AS, Sime-Ngando T (2008) Functional responses of prokaryotes and viruses to grazer effects and nutrient additions in freshwater microcosms. ISME $\mathrm{J} 2$ : 498-509

> Pradeep Ram AS, Boucher D, Sime-Ngando T, Debroas D, Romagoux JC (2005) Phage bacteriolysis, protistan bacterivory potential, and bacterial production in a freshwater reservoir: coupling with temperature. Microb Ecol 50: $64-72$

Pradeep Ram AS, Sabart M, Latour D, Sime-Ngando T (2009) Low effect of viruses on bacteria in deep anoxic water and sediment of a productive freshwater reservoir. Aquat Microb Ecol 55:255-265

Proctor LM, Fuhrman JA (1991) Roles of viral infection in organic particle flux. Mar Ecol Prog Ser 69:133-142
Sanders WR, Porter KG, Bennett SJ, DeBaise AE (1989) Seasonal patterns of bacterivory by flagellates, ciliates, rotifers, and cladocerans in a freshwater plankton community. Limnol Oceanogr 34:673-687

Sime-Ngando T, Colombet J (2009) Virus et prophages dans les écosystèmes aquatiques. Can J Microbiol 55: 95-109

Sime-Ngando T, Pradeep Ram AS (2005) Grazer effects on prokaryotes and viruses in a freshwater microcosm experiment. Aquat Microb Ecol 41:115-124

Sime-Ngando T, Mignot JP, Amblard C, Bourdier G, Devilettes C, Quilblier-Lloberas C (1996) Characterization of planktonic virus-like particles in a French mountain lake: methodological aspects and preliminary results. Ann Limnol 32:1-5

Šimek K, Pernthaler J, Weinbauer MG, Hornak K and others (2001) Changes in bacterial community composition and dynamics and viral mortality rates associated with enhanced flagellate grazing in a mesotrophic reservoir. Appl Environ Microbiol 67:2723-2733

Simon M, Azam F (1989) Protein content and protein synthesis rates of planktonic marine bacteria. Mar Ecol Prog Ser $51: 201-213$

Suttle CA (2007) Marine viruses - major players in the global ecosystem. Nat Rev Microbiol 5:801-812

Weinbauer MG (2004) Ecology of prokaryotic viruses. FEMS Microbiol Rev 28:127-181

Weinbauer MG, Höfle MG (1998) Significance of viral lysis and flagellate grazing as factors controlling bacterioplankton production in a eutrophic lake. Appl Environ Microbiol 64:431-438

- Weinbauer MG, Rassoulzadegan F (2004) Are viruses driving microbial diversification and diversity? Environ Microbiol $6: 1-11$

Weinbauer MG, Winter C, Höfle MG (2002) Reconsidering transmission electron microscopy based estimates of viral infection of bacterioplankton using conversion factors derived from natural communities. Aquat Microb Ecol 27: 103-110

Weinbauer MG, Brettar I, Höfle MG (2003a) Lysogeny and virus-induced mortality of bacterioplankton in surface, deep and anoxic marine waters. Limnol Oceanogr 48: $1457-1465$

Weinbauer MG, Christaki U, Nedoma J, Šimek K (2003b) Comparing the effects of resource enrichment and grazing on viral production in a meso-eutrophic reservoir. Aquat Microb Ecol 31:137-144

- Weinbauer MG, Hornàk K, Jezbera J, Nedoma J, Dolan JR, Šimek K (2007) Synergistic and antagonistic effects of viral lysis and protistan grazing on bacterial biomass, production and diversity. Environ Microbiol 9:777-788

Wilhelm SW, Matteson AR (2008) Freshwater and marine virioplankton: a brief overview of commonalities and differences. Freshw Biol 53:1076-1089

Wilhelm SW, Suttle CA (1999) Viruses and nutrient cycles in the sea. BioScience 49:781-788

Submitted: July 21, 2009; Accepted: September 30, 2009

Proofs received from author(s): January 16, 2010
Editorial responsibility: Gunnar Bratbak, Bergen, Norway 